\title{
PELATIHAN DASAR MENULIS BAGI GURU MADRASAH ALIYAH AT-TAMIMY PRAYA DI LOMBOK TENGAH
}

\author{
Sri Sofiati Umami \\ Universitas Islam Negeri Mataram, Mataram, Indonesia \\ sofie.umami@uinmataram.ac.id
}

\begin{abstract}
Abstrak: Kemajuan sebuah bangsa salah satunya ditentukan oleh kualitas sistem pendidikannya. Untuk memajukan sistem pendidikan dibutuhkan sumber daya manusia yaitu guru yang kompeten. Aktivitas menulis dapat mendukung pengembangan kemampuan akademik dan karier profesi guru. Pengabdian masyarakat ini bertujuan untuk melatih para guru madrasah mengenai teknik dasar menulis sehingga diharapkan setelah mengikuti kegiatan ini, para guru memiliki kesadaran untuk mengembangkan karier profesi guru melalui aktivitas menulis. Kegiatan ini dilaksanakan di Madrasah Aliyah Swasta At-tamimy, Praya, Kabupaten Lombok Tengah. Metode pengabdian masyarakat menggunakan pendekatan pelatihan yang bertujuan meningkatkan pengetahuan dan keterampilan dasar para guru dalam mencari literatur dan menulis kerangka tulisan. Hasil kegiatan ini adalah para guru telah memiliki keterampilan dalam literasi referensi secara daring sebagai bahan rujukan dalam menulis. Para guru masih belum mampu menyusun kerangka tulisan dengan baik. Pelatihan menulis berkelanjutan perlu terus dilakukan agar para guru termotivasi dan memiliki keterampilan untuk mengembangkan karier profesi melalui kegiatan menulis.
\end{abstract}

Kata Kunci: menulis, guru madrasah, karya ilmiah

\begin{abstract}
The quality of its education system determines the progress of a nation. Human resources, qualified teachers, are essential to improve the education system. Writing activities can support the development of academic skills and professional careers for teachers. This community service aimed to train teachers of a madrasah in basic writing techniques then after participating in this activity, it is expected that the teachers will have the awareness to develop professional teaching careers through writing activities. This activity was carried out at AtTamimy Madrasah Aliyah, Praya, Central Lombok Regency. The community service method used a training approach to increase teachers' basic knowledge and skills in searching for literature and writing written frameworks. This activity showed that the teachers have skills in online reference literacy as reference material in writing. However, teachers are still not able to develop a good writing framework. Continuous writing training needs to be carried out to be motivated and have the skills to create professional careers through writing activities.
\end{abstract}

Keywords: writing activities, teacher of the madrasah, scientific paper

\section{Pendahuluan}

Guru merupakan ujung tombak pelaksanaan sistem pendidikan. Keberhasilan dari suatu proses pembelajaran dapat dinilai dari capaian lulusan sekolah/madrasah yang diterima di perguruan tinggi terkemuka baik di dalam negeri maupun di luar negeri (Hand \& Prain, 2002). Hal tersebut menjadi cerminan dari kualitas dan keseriusan para guru dalam proses pembelajaran. Menyadari akan peran strategis guru ini, pemerintah telah menerbitkan sejumlah kebijakan untuk mendorong pengembangan profesionalisme guru, seperti melalui program sertifikasi guru yang diberikan sejumlah tunjangan kepada guru-guru yang telah memenuhi kualifikasi tertentu.

Kebijakan ini sejalan dengan tuntutan para guru untuk terus mengembangkan kemampuan profesionalnya dalam melaksanakan kegiatan pembelajaran di sekolah yang pada 
akhirnya, muara dari kebijakan tersebut adalah untuk meningkatkan kualitas pendidikan di Indonesia (Kemendikbud, 2010). Salah satu bentuk dari pengembangan profesi guru adalah kompetensi guru untuk membuat karya tulis ilmiah (Kemendikbud, 2010). Output dari kompetensi ini dapat diukur antara lain dari kemampuan siswa didiknya dalam menulis karya tulis ilmiah, keterlibatan guru dalam presentasi forum ilmiah, publikasi tulisan yang dimuat dalam jurnal ilmiah dan media lainnya, atau kemampuan guru menulis buku dan bahan ajar (Hakim, 2015). Kemampuan skill menulis diyakini dapat mengakselerasi profesionalisme guru sekaligus memperbaiki kualitas pembelajaran yang disampaikannya(Lam, 2019).

Karya ilmiah adalah karya tulis yang menyajikan data dari hasil penelitian atau analisis mendalam yang mengacu pada gagasan atau tulisan orang lain. Penulisannya menggunakan metode dan sistematika yang benar dan dapat dipertanggung-jawabkan (Wijayanti \& Arian, 2017). Sedangkan artikel ilmiah merupakan karya tulis yang disusun untuk dimuat dalam jurnal ilmiah yang mengikuti standar penulisan sebuah jurnal (Gunawan et al., 2018). Menulis merupakan soft-skill yang menuntut penguasaan terhadap suatu bidang atau topik tertentu, dengan menulis secara otomatis akan menjadi pembaca yang baik (Lam, 2019). Semakin baik referensi yang kita baca akan sejalan dengan output tulisan yang dihasilkan, sehingga kemampuan mencari literatur menjadi suatu keniscayaan. Literatur dapat membantu penulis menemukan ide atau gagasan tulisan, mengetahui kemajuan ilmu pengetahuan, menghindari duplikasi dan plagiasi, dan memilih metode penelitian yang tepat (Noorjannah, 2014).

Pada kenyataannya, minat dan kemampuan menulis para guru di Indonesia masih terbilang rendah, sehingga hal ini juga menjadi penghambat kemajuan guru terutama dalam hal kenaikan jenjang profesi guru (Wijayanti \& Arian, 2017) seperti yang dialami oleh para guru madrasah yang ada di daerah salah satunya di Kabupaten Lombok Tengah (Muhali et al., 2019). Berdasarkan hasil observasi dan wawancara dengan kepala madrasah dan sejumlah guru mata pelajaran di MA At-Tamimy Praya, aktivitas menulis menjadi kegiatan yang sangat dihindari, sehingga muncul para mental block dalam mindset guru seperti "saya tidak punya waktu menulis", "menulis sangat melelahkan", "saya tidak akan pernah bisa menulis", "tidak ada kejawajiban menulis bagi guru" dan keluhan lain yang menganggap menulis bukan kegiatan prioritas untuk meningkatkan kompetensi dan kualitas profesi guru.

Sejumlah penelitian melaporkan penyebab aktivitas menulis guru masih sangat rendah. Pertama, rendahnya minat membaca, kegiatan menulis sangat erat dengan membaca. Guru disibukkan dengan kegiatan mengajar (khususnya guru madrasah mengajar di kelas dan pesantren) sehingga membaca untuk meningkatkan kapasitas diri menjadi terlupakan. Kedua, kurang kesadaran untuk mencari bahan bacaan yang tersedia sebagai bahan tulisan. Ketiga, tidak ada percaya diri untuk memulai aktivitas menulis. Keempat, tidak ada motivasi untuk menulis. Kelima tidak memiliki keilmuan dan pengalaman untuk menulis (Marlena et al., 2017; Noorjannah, 2014).

Alasan pemilihan lokasi pengabdian di Madrasah Aliyah At- Tamimy Berangsak adalah Pertama, MA At-Tamimy merupakan lembaga pendidikan Islam swasta yang berdiri pada tahun 2016 sehingga masih banyak aspek akademik yang perlu dibenahi terutama dari sisi kualitas guru. Kedua, aktifitas para guru sangat padat dan sedikit kesempatan yang bisa dilakukan untuk 
pengembangan diri dalam hal akademik. Hal ini disebabkan oleh MA At-Tamimy merupakan madrasah yang berada di bawah naungan yayasan pondok pesantren At-Tamimy, sebagian para guru yang mengajar di madrasah juga mengajar di pesantren. Ketiga, Madrasah Aliyah AtTamimy memiliki 15 guru tetap yayasan yang masih banyak belum memiliki gurunya belum tersertifikasi. Pelatihan dan pendampingan ini diharapkan sebagai inisiasi untuk mengenalkan ilmu dasar menulis sehingga nantinya dapat membantu meningkatkan kemampuan guru dalam menghasilkan karya tulis. Keempat, MA At- Tamimy bukan merupakan satu-satunya lembaga pendidikan yang ada di lingkungan pondok pesantren At-Tamimy, melainkan terdapat SMP Islam, sehingga kegiatan pelatihan ini tidak terbatas pada guru madrasah Aliyah saya melainkan dapat merangkul semua guru yang mengabdi di yayasan pondok pesantren At-Tamimy.

Beranjak dari kondisi tersebut, tim pengabdi merasa penting untuk dilakukan bimbingan pengetahuan dasar bagi para guru madrasah untuk menulis. Pengabdian ini merupakan sebuah inisiasi awal untuk melatih para guru dengan lingkup pelatihan menulis karya tulis ilmiah dengan fokus pelatihan: (1) memperkenalkan para guru tentang membangun motivasi menulis karya ilmiah (2) memberikan pemahaman dasar tentang bagaimana teknik menulis karya ilmiah, yang meliputi menelusur bahan rujukan dan menyusun kerangka tulisan (outline).

\section{Metode}

Metode pengabdian yang digunakan untuk mencapai tujuan dalam pengabdian ini adalah melalui pendekatan pelatihan untuk tujuan memperkenalkan keterampilan dasar menulis karya ilmiah kepada para madrasah antara lain menemukan ide/gagasan melalui penelusuran referensi online dan menyusun kerangka tulisan. Pelatihan dasar menulis dilaksanakan di Madrasah Aliyah At-tamimy Berangsak, Praya Lombok Tengah pada bulan Juli 2018. Persiapan kegiatan dilakukan selama 2 minggu dan pelatihan menulis dilaksanakan selama selama 1 hari. Sasaran dari kegiatan ini adalah para guru Madrasah Aliyah yang berjumlah 15 orang. Mitra madrasah pada kegiatan pengabdian ini dilibatkan sepenuhnya dalam penentuan topik kegiatan antara lain analisis masalah dan kebutuhan skill tentang menulis, penentuan waktu pelatihan, penyusunan modul pelatihan, fasilitas yang dibutuhkan pada kegiatan pelatihan. Alur pelaksanaan pengabdian dapat dilihat pada gambar 1. Pengabdian masyarakat ini dilaksanakan melalui beberapa tahapan yaitu:

a. Tim pengabdi membuat rencana kerja yang tersistem dalam rancangan skill dasar pelatihan menulis yang akan diberikan kepada peserta pelatihan.

b. Tim pengabdi mulai melakukan sosialisasi dan observasi kepada Kepala madrasah, perangkat madrasah serta perwakilan guru madrasah Aliyah at-tamimy tentang pentingnya skill menulis bagi guru. Tahap ini bertujuan untuk memperoleh informasi awal mengenai skill menulis yang dibutuhkan oleh para guru madrasah sehingga diputuskan topik tentang cara menemukan ide penelitian melalui penelurusan literatur dan teknik dasar menyusun kerangka tulisan.

c. Narasumber/ tim pengabdi mempersiapkan handout panduan pelatihan menulis sesuai dengan topik yang telah disepakati bersama. 
d. Narasumber/dosen bersama tim melaksanakan pelatihan menulis

e. Tim pengabdi melakukan evaluasi secara lisan kepada seluruh peserta mengenai proses pelatihan yang telah dilakukan

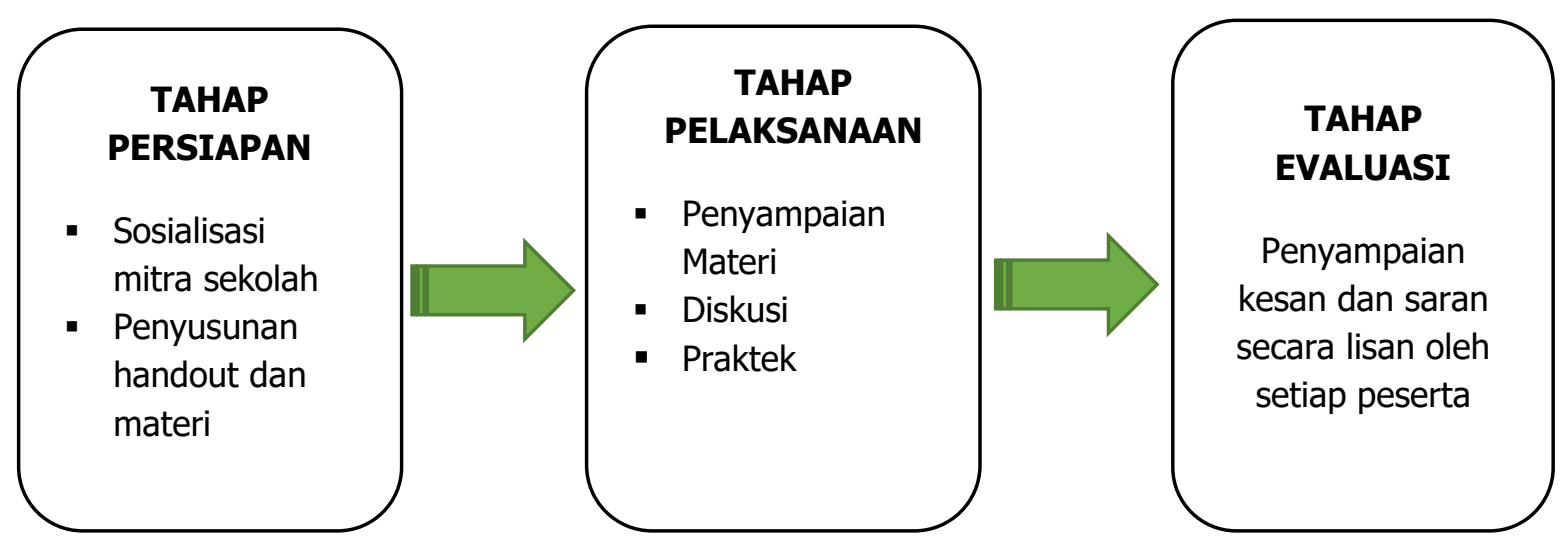

Gambar 1. Skema pelaksanaan pengabdian

\section{Hasil dan Pembahasan}

\section{Pelaksanaan Pengabdian Masyarakat}

Secara garis besar kegiatan pengabdian masyarakat ini terbagi dalam tiga sesi, yaitu sesi pertama presentasi mengenai motivasi membangun keinginan menulis, sesi kedua adalah menelusur referensi ilmiah dan ketiga yaitu belajar menyusun kerangka tulisan. Uraian kegiatan disajikan pada tabel 1.

Tabel 1. Agenda pelaksanaan kegiatan pengabdian masyarakat.

\begin{tabular}{cclc}
\hline No & Waktu & \multicolumn{1}{c}{ Uraian Kegiatan } & \multicolumn{1}{c}{ Penanggungjawab } \\
\hline 1 & $08.00-08.30$ & Pembukaan & Pengabdi dan Kepala Madrasah \\
\hline 2 & $08.30-09.30$ & $\begin{array}{l}\text { Materi 1: Membangun motivasi } \\
\text { menulis }\end{array}$ & Narasumber 1 \\
\hline 3 & $09.30-10.00$ & Diskusi & Narasumber 1 \\
\hline 4 & $10.00-10.15$ & Istirahat & Nim pengabdi \\
\hline 5 & $10.15-11.15$ & $\begin{array}{l}\text { Materi 2: Menelusur referensi ilmiah } \\
\text { secara online }\end{array}$ & Narasumber 2 \\
\hline 6 & $11.15-12.00$ & Diskusi dan Praktek & Tim pengabdi \\
\hline 7 & $12.00-13.00$ & Istirahat & Narasumber 2 \\
\hline 6 & $13.30-14.30$ & $\begin{array}{l}\text { Materi 3: Menyusun kerangka } \\
\text { tulisan }\end{array}$ & Narasumber 2 \\
\hline 7 & $14.30-15.00$ & Diskusi dan Latihan & Tim Pengabdi \\
\hline 8 & $15.00-15.30$ & Evaluasi Peserta & \\
\hline
\end{tabular}

Pada materi yang pertama, narasumber memberikan uraian tentang urgensi menulis untuk pengembangan diri dan profesi. Menulis bisa dimulai dari hobi yang diambil dari kegiatan sehari-hari, misalnya menulis aktivitas harian, bagi para guru yang sudah menjadi ibu rumah tangga, menulis resep masakan bisa menjadi langkah awal menumbuhkan motivasi menulis. Kegiatan menulis harus dilakukan secara konsisten dan membutuhkan waktu. Menulis bisa menjadi profesi jika ditekuni dengan serius. Pemateri juga memberikan contoh penulis inspiratif dari berbagai profesi yang karya tulis/ bukunya memiliki segmen pembacanya sendiri seperti 
Prof. Quraish shihab, Dewi Lestari, Asma nadia, Rhenald Kasali dan lain-lain.

Selanjutnya menulis karya ilmiah untuk kepentingan akademik profesi. Pembicara memperkenalkan berbagai bentuk karya ilmiah dalam bidang pendidikan antara lain: artikel jurnal hasil penelitian atau review dari berbagai literatur ilmiah, hasil survei, buku pelajaran, karya terjemahan, tulisan ilmiah popular seperti di media cetak dan online, hasil konferensi ilmiah (Dwijayanti et al., 2017). Pelatihan pada kegiatan ini masih berupa pelatihan dasar dan awal, sehingga materi yang diberikan berupa bagaimana strategi mencari literatur yang bisa dijadikan rujukan dalam menulis. Bahan baku tulisan yang baik adalah bacaan/ referensi yang bermutu.

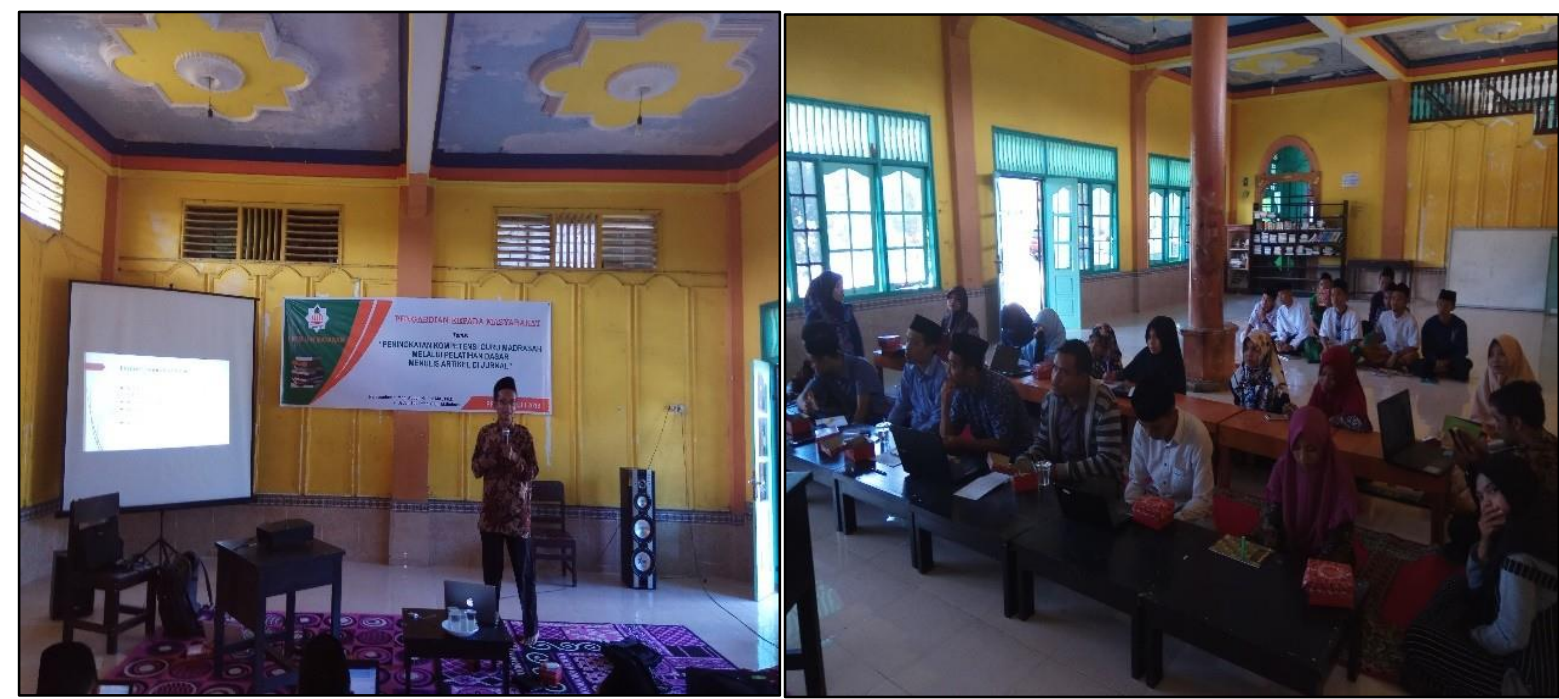

Gambar 2. Tim Pemateri (Editor in Chief Jurnal Ulumuna UIN Mataram) mempresentasikan teknik dasar penulisan kepada para guru MA At-tamimy.

\section{Penelusuran literatur sebagai bahan tulisan (Literasi Informasi)}

Kemampuan menulis dapat dilatih dengan belajar melakukan analisis dan sintesis dari permasalahan yang sesuai dengan bidang keahlian. Kemudian hasil analisis tersebut menjadi bahan sebuah tulisan. Menulis merupakan aktivitas yang bisa ditekuni oleh berbagai macam profesi termasuk guru. Guru merupakan profesi yang tidak terlepas dari kegiatan menulis, seperti menulis rencana pelaksanaan pembelajaran, silabus pembelajaran, dan instrumen evaluasi hasil belajar siswa hingga menganalisis hasil belajar siswa (Gunawan et al., 2018). Namun pada kenyataannya, kemampuan guru dalam menulis karya ilmiah masih lemah. Lemahnya kemampuan menulis ilmiah para guru antara lain akibat dari kesulitan mengakses informasi dan juga penguasaan teknik penulisan (Caswita, 2020). Oleh sebab itu, menjadi hal penting bagi guru untuk membaca referensi yang bersumber dari hasil penelitian seperti jurnal.

Pemateri menyampaikan materi tentang teknik mencari literatur/ rujukan dari beberapa sumber online. Untuk referensi berbahasa Indonesia, laman http://garuda.ristekbrin.go.id/ menjadi pilihan karena memuat jutaan artikel ilmiah dari ribuan jurnal ilmiah. Peserta cukup mengetikkan topik penelitian di kolom "search" (gambar 2). Lalu akan muncul puluhan hingga ratusan artikel dengan tema yang sama. Semakin umum kata kunci yang dimasukkan, maka semakin banyak artikel yang muncul, begitu pula sebaliknya. Pemilihan kata kunci yang spesifik 
menjadi kunci untuk menemukan artikel yang tepat dan dibutuhkan oleh penulis. Untuk dapat membaca artikel, pengguna cukup mengarahkan kursor pada judul artikel yang diinginkan. Jika peserta tertarik untuk membaca lebih dalam, artikel dapat diunduh dengan mudah karena semua artikel yang ada di laman garudaristekdikti bersifat open acces. Pada kegiatan ini peserta guru banyak yang tidak membawa laptop, sehingga pemateri mengarahkan peserta untuk menggunakan ponsel pintarnya masing-masing.

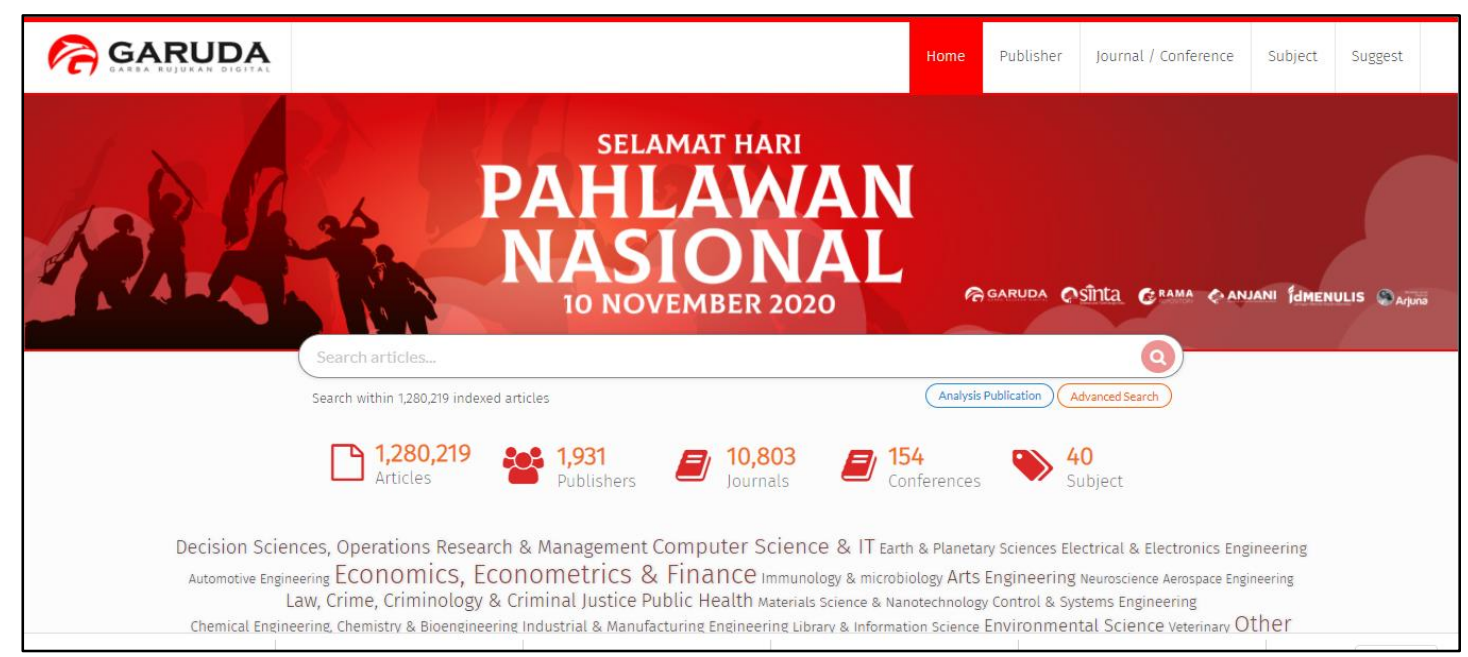

Gambar 3. Laman garudaristekdikti salah satu sumber referensi jurnal Bahasa Indonesia

Tentunya tidak semua artikel yang ditemukan di media online dapat dijadikan sumber bacaan yang reliabel. Oleh sebab itu, perlu dilakukan teknik literasi berikutnya dengan melacak ke laman jurnal yang menerbitkan artikel tersebut melalui laman https://sinta.ristekbrin.go.id (gambar 3). Apabila jurnal yang diterbitkan tersebut telah diindeksasi pada Sinta (S1 sampai dengan S6), artikel tersebut dapat dipertanggungjawabkan kebenarannya. Tentunya makin tinggi rangking Sinta (S1 dan S2), sejalan dengan kualitas sebuah artikel yang semakin baik. Dari pelatihan ini, para peserta mendapatkan pengetahuan baru bahwa tidak semua artikel jurnal yang diperoleh di internet bisa dijadikan bahan rujukan dalam menulis karya ilmiah.

\section{Menemukan Ide/gagasan artikel ilmiah}

Pemateri menyampaikan tips dan trik untuk mendapatkan ide dan inspirasi tulisan. Cara untuk menemukan ide tulisan antara lain: Pertama, mencari literatur di perpustakaan setempat atau internet. Tips kedua yaitu membaca artikel jurnal hasil penelitian dan melihat problem yang belum diselesaikan pada bagian saran. Umumnya peneliti akan menyampaikan bagian apa yang belum dilakukan, misalnya metode, subjek dan objek penelitian yang digunakan. Sebagai pemula, dapat melihat metode penelitian yang mudah dikuasai dan memilih ide penelitian yang sesuai dengan metode tersebut. Strategi berikutnya yang dapat dilakukan adalah dengan berpartisipasi aktif di dalam organisasi profesi, pertemuan rutin, seminar, dll. Interaksi guru dengan dunia pendidikan, dinamika aturan serta kebijakannya membuat guru untuk berpikir kritis dan melahirkan ide-ide kreatif dan inovatif (Trisniawati et al., 2018). Sebagai guru, ide/ gagasan dapat ditemukan di kelas saat mengajar (Sumartini et al., 2019), sehingga interaksi guru dan siswa di kelas merupakan bahan penelitian dan tulisan. Selain itu, berpartisipasi dalam 
kompetisi penulisan karya ilmiah untuk guru dan murid juga merupakan peluang menemukan inspirasi ide penelitian.

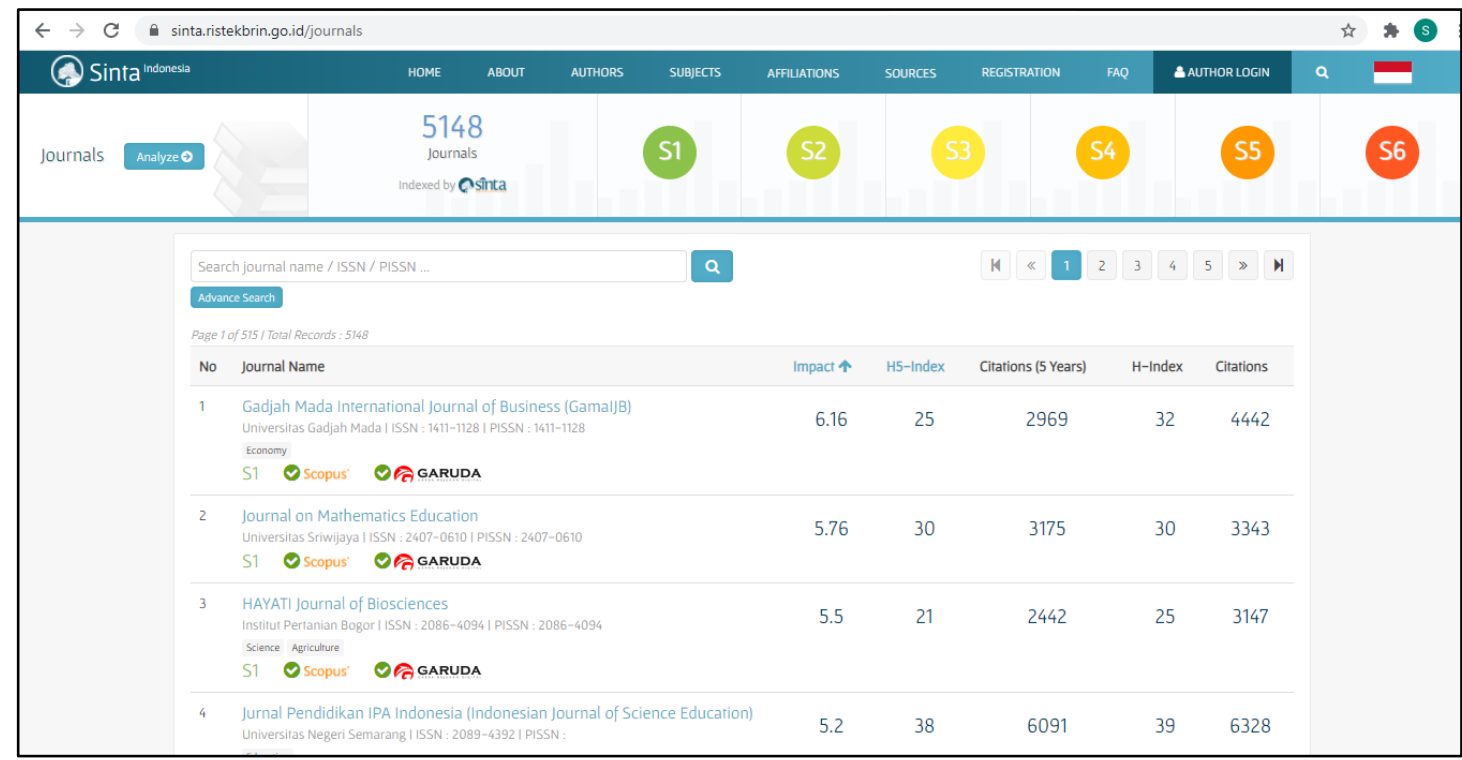

Gambar 4. Laman sinta ristekbin, pengindeks akreditasi nasional jurnal ilmiah di Indonesia

Para peserta sangat antusias mengikuti sesi ini yang dibuktikan dengan 7 peserta melontarkan pertanyaan seperti bagaimana mengetahui sebuah artikel jurnal yang baik dan tepat untuk dijadikan sebagai sumber rujukan, apakah blog atau berita online bisa digunakan sebagai bahan tulisan, bila sudah memiliki ide lalu bagaimana memulai menulis, apakah menulis bisa jadi penghasilan tambahan, apakah boleh melakukan plagiasi untuk penulis pemula, bagaimana cara membagi waktu menulis bagi guru yang sudah berumahtangga.

\section{Menyusun Kerangka Tulisan}

Pelatihan berikutnya adalah teknik menyusun kerangka tulisan. Kerangka (outline) tak ubahnya adalah daftar isi dari sebuah tulisan. Kendala yang umum dihadapi oleh penulis pemula adalah kebingungan untuk memulai menulis. Dari hasil PKM ini, sejumlah peserta menanyakan hal pertama apa yang harus dituliskan, lalu bagaimana merangkai susunan kalimat menjadi Alinea. Menurut (Noey, 2000), kebingungan yang muncul ini disebabkan pikiran bawah sadar kita berebut mengeluarkan ide mengenai apa yang ingin dituliskan lebih dahulu atau bisa juga sebaliknya memang tidak ada ide yang ingin dituangkan. Kebingungan yang lain adalah kata yang ingin digunakan. Bagi penulis pemula, sering tertukar antara bahasa lisan dan tulisan, formal dan non-formal. Dalam konteks tulisan ilmiah, tentu saja penulis harus bisa menggunakan bahasa formal.

Tahap awal menulis antara lain menentukan tema tulisan adalah menuliskan judul atau topik atau subtopik yang terkait dengan gagasan yang ditentukan. Biarkan semua judul/subjudul tertuang tanpa harus mengurutkannya secara logis. Setelah semua ide tulisan disusun, mulailah dengan mencermati setiap kalimat, susun kembali menjadi sebuah alur bacaan dari umum ke khusus (spesifik). Kemudian menentukan gagasan utama yang akan dibahas pada setiap paragraf dan mengembangkan setiap topik tulisan sampai menjadi paragraf yang utuh. 
Setelah mengamati susunan kalimat, dilakukan pengecekan kembali apakah ada yang perlu dihilangkan, ditambahkan atau dipindahkan posisinya. Pemateri berpesan untuk tidak sering mengoreksi tulisan karena penyuntingan dapat dilakukan di tahap akhir apabila semua tulisan telah menjadi sebuah artikel utuh. Jika telah selesai menyusun kerangka (outline), maka dapat dilanjutkan dengan menyusun tulisan secara utuh. Dari hasil PKM ini, hanya ada 1 peserta yang menyusun kerangka tulisan seperti yang sajikan pada gambar 5 .

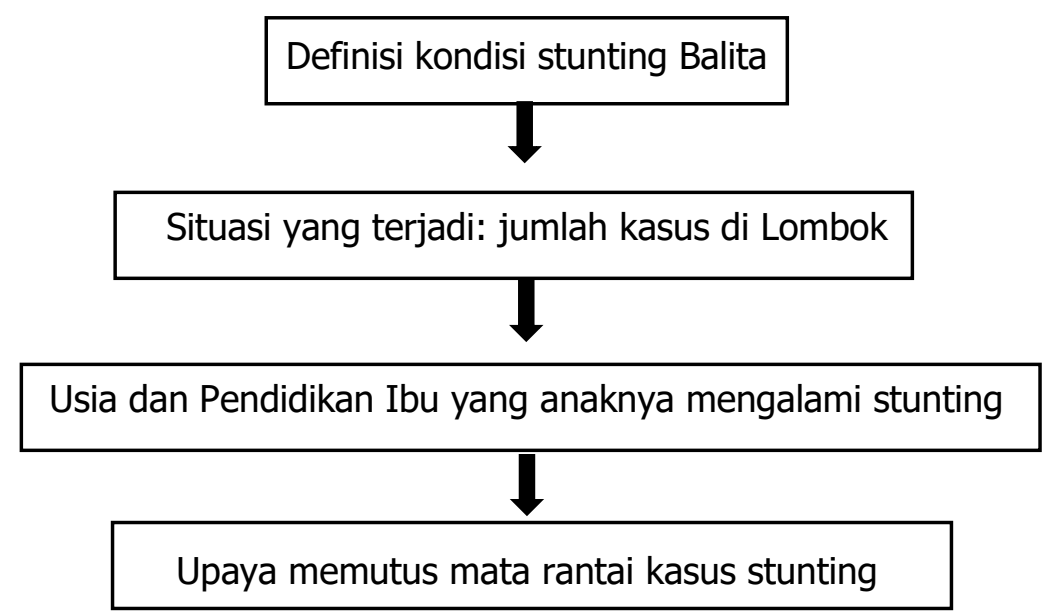

Gambar 5. Outline tulisan diambil dari peserta yang berjudul "Kasus Stunting di Lombok"

Dalam sesi review hasil kerangka tulisan yang diperoleh dari peserta, ditemukan kesalahan dalam penggunaan bahasa. Para peserta masih bingung memilih kata yang digunakan untuk bahasa lisan dan tulisan. Penguasaan bahasa Indonesia yang baku masih kurang, karena ditemukan dengan memasukan kata dalam bahasa daerah (sasak). Selain itu para guru juga kesulitan dalam menyusun kalimat yang efektif. Komposisi kata yang digunakan banyak diulang sehingga beberapa kalimat bermakna sama dan tidak mengalir seperti sebuah paragraf yang baik.

Pendampingan menulis yang berkelanjutan guna meningkatkan profesionalisme guru perlu terus dilakukan. Kegiatan PKM ini menjadi sebuah inisiatif yang dapat dilanjutkan pelaksanaannya baik dari pihak sekolah, maupun melalui forum musyawarah guru mata pelajaran (MGMP) atau Kelompok Kerja Guru (KKG). Menurut Noey (2000), pelatihan guru hendaknya menjadi sebuah upaya yang direncanakan secara bersinergi untuk meningkatkan penguasaan kompetensi guru antara lain penguasaan pengetahuan, skill serta sikap dalam mewujudkan tugas profesionalnya. Pelatihan menulis semacam ini perlahan tapi pasti dapat memperbaiki kinerja guru yang disebabkan oleh kurang pengetahuan dan keterampilan menulis.

Aktifitas menulis dapat menambah skill yang sejalan dengan kemajuan digitalisasi pendidikan sehingga dapat diimplementasikan juga dalam kegiatan mengajar di kelas. Pelatihan menulis juga dapat difokuskan untuk membekali para guru baru yang minim pengalaman agar kompeten dalam pekerjaan, karena seringkali guru baru tidak menguasai keahlian dan kemampuan yang dibutuhkan dalam menjalankan pekersjaanya. Menulis bagi guru pada akhirnya akan mengembangkan karir guru yang tidak terbatas hanya berperan di sekolah saja. Untuk mewujudkan tujuan tersebut diperlukan sinergi antara pimpinan madrasah, para guru 
dan kelompok kerja guru agar pengetahuan menulis dapat terus dibentuk, dilatih dan didampingi.

\section{Kesimpulan}

Hasil kegiatan pengabdian ini secara umum mencakup beberapa komponen sebagai berikut: 1) Keberhasilan target jumlah peserta seperti direncanakan adalah dihadiri oleh 15 guru di MA At-tamimy Praya Lombok Tengah. 2) Dalam hal ketercapaian tujuan pelatihan skill penelusuran referensi ilmiah, para peserta mampu mencari literatur berpedoman petunjuk yang diberikan selama pelatihan. Namun dalam materi menyusun kerangka tulisan, hanya satu peserta yang berhasil menyusun kerangka tulisan yang sederhana. 3) Ketercapaian target materi pada kegiatan pengabdian ini terbilang cukup baik, sebagian peserta aktif mengajukan berbagai pertanyaan mengenai karakteristik artikel yang baik dan teknik melatih diri untuk menyusun kerangka tulisan yang tepat. Kegiatan ini masih merupakan tahap awal untuk mengenalkan para guru mengenai konsep/ teori penulisan karya ilmiah sehingga pelatihan lanjutan yang intensif perlu dilakukan.

\section{Ucapan Terima Kasih}

Pengabdian ini dapat terlaksana atas Hibah Pengadian Masyarakat dari Lembaga Penelitian dan Pengabdia Masyarakat (LP2M) Universitas Islam Negeri Mataram. Penulis juga menyampaikan terimakasih dan apresiasi yang mendalam atas kerjasama pihak Yayasan Pondok pesantren At-tamimy, Berangsak, Praya Lombok Tengah dan Guru-guru Madrasah Aliyah At-tamimy atas Kerjasama dan partisipasinya selama mengikuti rangkaian kegiatan.

\section{Referensi}

Caswita. (2020). Forum Gumeulis: Upaya Peningkatan Kompetensi Guru dalam Menulis Karya IImiah di Kota Tasikmalaya. Andragogi: Jurnal Diklat Teknis Pendidikan Dan Keagamaan, 8(1), 418429. https://doi.org/10.36052/andragogi.v8i1.122

Dwijayanti, R., Marlena, N., \& Patrikha, F. D. (2017). Pelatihan Penulisan Karya Tulis (KTI) Bagi Guru-guru SMK di Kabupaten Jombang. Jurnal Pemberdayaan Masyarakat Madani (JPMM), 1(2), 249-266. https://doi.org/10.21009/jpmm.001.2.07

Gunawan, I., Triwiyanto, T., \& Kusumaningrum, D. E. (2018). Pendampingan Penulisan Artikel Ilmiah bagi Para Guru Sekolah Menengah Pertama. Abdimas Pedagogi: Jurnal Ilmiah Pengabdian Kepada Masyarakat, 1(2), 128-135. www.sciencedirect.com;

Hakim, A. (2015). Contribution of Competence Teacher (Pedagogical, Personality, Professional Competence and Social) On the Performance of Learning. The International Journal of Engineering And Science, 4(2), 1-12. www.theijes.com

Hand, B., \& Prain, V. (2002). Teachers Implementing Writing-To-Learn Strategies in Junior Secondary Science: A Case Study. Science Education, 86(6), 737-755. https://doi.org/10.1002/sce.10016

Kemendikbud. (2010). Permendiknas Nomor 35 Tahun 2010 tentang Petunjuk Teknis Pelaksanaan Jabatan Fungsional Guru dan Angka Kreditnya. Pusat Pengembangan Tenaga Kependidikan.

Lam, R. (2019). Teacher assessment literacy: Surveying knowledge, conceptions and practices of classroom-based writing assessment in Hong Kong. System, 81, 78-89. https://doi.org/10.1016/j.system.2019.01.006

Marlena, N., Dwijayanti, R., Patrikha, F. D., \& Parjono, P. (2017). Pelatihan Penulisan Karya Tulis 
Transformasi: Jurnal Pengabdian Masyarakat, Vol. 16, No. 2, Desember 2020: 203-212

Ilmiah (KTI) Bagi Guru Sma Swasta Di Sidoarjo. Jurnal ABDI, 2(2), 45. https://doi.org/10.26740/ja.v2n2.p45-50

Muhali, M., Prayogi, S., Asy'ari, M., Hunaepi, H., Sukarma, I. K. S. K., Mirawati, B., Syamsuri, T. S., Firdaus, L., \& Fitriani, H. (2019). Pelatihan Guru MIPA MAN 3 Lombok Tengah dalam Menyusun Perangkat Pembelajaran yang Melatihkan Kemampuan Metakognisi Siswa. BAKTIMAS: Jurnal Pengabdian Pada Masyarakat, 1(1), 49. https://doi.org/10.32672/btm.v1i1.1182

Noey, R. A. (2000). Human resource management: gaining competitive advantage, 5th ed. McGraw Hill. Noorjannah, L. (2014). Pengembangan Profesionalisme Guru Melalui Penulisan Karya Tulis IImiah Bagi Guru Profesional Di Sma Negeri 1 Kauman Kabupaten Tulungagung. Jurnal Humanity, 10(1), 98-114.

Sumartini, Mulyani, M., \& Nugroho, B. A. (2019). Workshop Penulisan Karya Ilmiah Bagi Guru. Jurnal Puruhita, 1(1), 54-59. https://journal.unnes.ac.id/sju/index.php/puruhita/

Trisniawati, T.-, Wardani, K., \& Azizah, D. M. (2018). Optimalisasi Penulisan Karya Tulis Ilmiah Pada Guru Sd Negeri Jetis 2 Yogyakarta. Abdimas Dewantara, 1(1), 77. https://doi.org/10.30738/ad.v1i1.2086

Wijayanti, S. H., \& Arian, Y. D. (2017). Penulisan Karya IImiah Guru Sekolah Dasar Pascapelatihan. Jurnal Pendidikan Dasar PerKhasa, 3(2), 447-461. https://doi.org/https://doi.org/10.31932/jpdp.v3i2.94 